\title{
Optimasi Dosis Pupuk Kalsium dan Magnesium pada Bibit Kelapa Sawit (Elaeis guineensis Jacq.) di Pembibitan Utama
}

\author{
Dose Optimization of Calcium and Magnesium Fertilizer for \\ Oil Palm (Elaeis guineensis Jacq.) Seedling in Main Nursery
}

\author{
Eltis Panca Ningsih ${ }^{1,2}$, Sudradjat $^{3^{*}}$, dan Supijatno ${ }^{3}$ \\ ${ }^{1}$ Program Studi Agronomi dan Hortikultura, Sekolah Pascasarjana, Institut Pertanian Bogor \\ ${ }^{2}$ Jurusan Agroekoteknologi, Fakultas Pertanian, Universitas Sultan Ageng Tirtayasa \\ Jl. Raya Jakarta KM. 04 Pakupatan, Serang 42124, Indonesia \\ ${ }^{3}$ Departemen Agronomi dan Hortikultura, Fakultas Pertanian, Institut Pertanian Bogor \\ (Bogor Agricultural University), Jl. Meranti, Kampus IPB, Darmaga, Bogor 16680, Indonesia
}

Diterima 5 Mei 2014/Disetujui 1 September 2014

\begin{abstract}
Oil palm is one of the important plantation crops in the plantation sector. Increased oil palm plantation area causes the need for the availability of oil palm seedlings in large quantities. Good quality oil palm seedlings were obtained through intensive maintenance especially fertilization. Fertilizers needed for the growth of oil palm seedlings include calcium and magnesium fertilizers. The objective of this experiment was to determine the optimum rates of calcium and magnesium fertilizer for oil palm seedling (Elaeis guineensis Jacq.). This experiment was conducted at Cikabayan Experimental Station, IPB Darmaga, Bogor, from December 2011 to November 2012. The experimental design used was factorial randomized block design with three replications. The first factor was Ca fertilizer rates i.e., 0, 5, 10, and $20 \mathrm{~g} \mathrm{CaCO}_{3}$ plant $^{-1}$. The second factor was $\mathrm{Mg}$ fertilizer rates, i.e., 0, 24, 48, and $96 \mathrm{~g} \mathrm{MgSO}{ }_{4}$ plant $^{-1}$. The results showed that calcium affected stomatal density, whereas magnesium fertilizer affected morphological and physiological variables (stomatal density and chlorophyll content) of oil palm seedling. Based on the plant height and stem diameter, the recommended rate of magnesium fertilizer for 8 months oil palm seedlings in the main nursery was $58 \mathrm{~g}$ plant ${ }^{-1}$. This total rate should be applied at different amount every month from 1-8 month, at 2.0, 2.0, 8.0, 9.3, 8.8, 9.3, 9.4 and $9.3 \mathrm{~g} \mathrm{MgSO}_{4}$ plants $^{-1}$ respectively. The optimum rate of calcium fertilizer was not able to be determined in this research.
\end{abstract}

Keywords: chlorophyll, leaf, morphology, physiology

\section{ABSTRAK}

Kelapa sawit merupakan salah satu tanaman perkebunan yang penting di sektor perkebunan. Peningkatan luas areal perkebunan kelapa sawit menyebabkan diperlukannya ketersediaan bibit kelapa sawit dalam jumlah besar. Bibit kelapa sawit yang baik diperoleh melalui pemeliharaan yang intensif terutama pemupukan. Pupuk yang dibutuhkan bibit kelapa sawit antara lain adalah pupuk kalsium dan magnesium. Penelitian ini bertujuan untuk menentukan dosis optimum pupuk kalsium dan magnesium pada bibit kelapa sawit (Elaeis guineensis Jacq.). Penelitian dilaksanakan di Kebun Percobaan IPB Cikabayan, Darmaga, Bogor, mulai bulan Desember 2011 sampai dengan Nopember 2012. Percobaan ini menggunakan rancangan kelompok lengkap teracak faktorial dengan tiga ulangan. Faktor pertama adalah dosis pupuk Ca, terdiri atas 0, 5, 10, dan $20 \mathrm{~g} \mathrm{CaCO}_{3}$ per tanaman. Faktor ke dua adalah dosis pupuk $\mathrm{Mg}$, terdiri atas 0, 24, 48, and $96 \mathrm{~g} \mathrm{MgSO} \mathrm{ger}^{\mathrm{p}}$ tanaman. Hasil penelitian menunjukkan bahwa pemberian pupuk kalsium berpengaruh pada kerapatan stomata, sedangkan pupuk magnesium berpengaruh nyata terhadap peubah morfologi dan fisiologi bibit kelapa sawit yaitu pada peubah kerapatan stomata dan kandungan klorofil. Berdasarkan peubah tinggi tanaman dan diameter batang maka dosis optimum pupuk magnesium bibit kelapa sawit selama 8 bulan di pembibitan utama adalah $58 \mathrm{~g}$ per tanaman. Dosis pupuk Mg tersebut diaplikasikan setiap bulannya dalam jumlah yang berbeda pada umur 1-8 bulan, berturut-turut adalah 2.0, 2.0, 8.0, 9.3, 8.8, 9.3, 9.4, dan $9.3 \mathrm{~g} \mathrm{MgSO}_{4}$ per tanaman. Dosis optimum pupuk kalsium tidak dapat ditentukan pada penelitian ini.

Kata kunci: daun, fisiologi, klorofil, morfologi

* Penulis untuk korespondensi. e-mail: sudradjat_ipb@yahoo.com 


\section{PENDAHULUAN}

Kelapa sawit merupakan salah satu tanaman perkebunan yang menduduki posisi penting di sektor perkebunan. Perkebunan kelapa sawit dari tahun ke tahun mengalami peningkatan. Luas perkebunan kelapa sawit Indonesia pada tahun 2001 sebesar 4.16 juta ha dan pada tahun 2012 seluas 9.1 juta ha dengan rata-rata pertumbuhan sebesar $0.98 \%$ per tahun. Produksi CPO Indonesia sepanjang sepuluh tahun terakhir terus mengalami peningkatan sebesar $1.84 \%$ per tahun. Produksi CPO di Indonesia pada tahun 2000 mencapai 7 juta ton dan pada tahun 2012 telah meningkat menjadi 23.5 juta ton (Ditjenbun, 2013). Produktivitas minyak kelapa sawit yaitu CPO sebesar 4.08 ton $\mathrm{ha}^{-1}$, sedangkan produktivitas minyak nabati dari kedelai, bunga matahari dan rapeseed masing-masing sebesar 0.38 , 0.60 dan 0.75 ton ha $^{-1}$ (MPOB, 2011).

Peningkatan luas areal perkebunan kelapa sawit menyebabkan diperlukannya ketersediaan bibit kelapa sawit dalam jumlah besar. Bibit kelapa sawit yang baik diperoleh melalui pemeliharaan yang intensif terutama pemupukan. Pemupukan merupakan faktor penentu utama, khususnya keseimbangan dosis dan jenis pupuk yang digunakan dan bukan pada tingkat dosis yang tinggi (Wachjar dan Kadarisman, 2007). Percobaan pemupukan perlu dilakukan untuk memperoleh dosis pemupukan yang optimum karena biaya pupuk dalam pengelolaan perkebunan kelapa sawit secara intensif sekitar 50-70\% dari biaya pemeliharaan dan $25 \%$ dari seluruh biaya produksi (Fairhurst et al., 2006).

Kalsium dan magnesium merupakan hara makro sekunder. Kalsium berperan sebagai nutrisi tanaman yang diperlukanuntukpertumbuhan dan perkembangan khususnya akar dan tunas (Tuteja dan Mahajan, 2007). Gejala tanaman yang kekurangan Ca yaitu terhambatnya pertumbuhan pucuk (titik tumbuh), kemudian pertumbuhan tanaman kerdil dan mati (Baker dan Pilbean, 2006). Magnesium dibutuhkan dalam aktivitas enzim-enzim dan sebagai atom pusat dari molekul klorofil. Magnesium mengaktifkan enzim ribulose1,5-bisphosphate (RuBP) carboxylase yang penting dalam proses fotosintesis (Cakmak dan Yazici, 2010; Gransee dan Fuhrs, 2012; Yang et al., 2012). Aplikasi nitrogen (N) dan potasium $(\mathrm{K})$ dalam tanah tanpa pemberian $\mathrm{Mg}$ dapat menyebabkan defisiensi magnesium (khlorosis). Gejala kahat Mg pada tanaman kelapa sawit disebut dengan istilah "orange frond" dan pada tingkat kekahatan berat khlorosis diikuti oleh nekrosis (Oviasogie et al., 2011).
Penelitian ini bertujuan untuk mengetahui pengaruh pemupukan kalsium, magnesium, interaksi antara pupuk kalsium dengan magnesium terhadap bibit kelapa sawit dan menentukan dosis optimum unsur kalsium dan magnesium pada bibit kelapa sawit.

\section{BAHAN DAN METODE}

Penelitian dilaksanakan di kebun percobaan IPB, Cikabayan, Darmaga, Bogor. Jenis tanah adalah Latosol dan terletak pada ketinggian $250 \mathrm{~m}$ di atas permukaan laut. Penelitian dilaksanakan mulai bulan Desember 2011 sampai dengan Nopember 2012.

Bahan-bahan yang digunakan dalam penelitian ini adalah bibit kelapa sawit Tenera Dami Mas (nomor persilangan $44 \times 19.10$ ) yang berumur 4 bulan, tanah lapisan atas (top soil), polybag berukuran $50 \mathrm{~cm}$ x $40 \mathrm{~cm}$, kapur pertanian $\left(\mathrm{CaCO}_{3}\right)$, dan Epsom salt $\left(\mathrm{MgSO}_{4} 7 \mathrm{H}_{2} \mathrm{O}\right)$.

Penelitian ini disusun menggunakan rancangan kelompok lengkap teracak faktorial. Faktor pertama adalah dosis pemupukan $\mathrm{CaCO}_{3}$ dengan 4 taraf, yaitu 0 (kontrol), 5, 10, $20 \mathrm{~g} \mathrm{CaCO}_{3}$ per tanaman. Faktor kedua adalah dosis total pemupukan $\mathrm{MgSO}_{4}$ dengan 4 taraf, yaitu 0 (kontrol), 24, 48, $96 \mathrm{~g} \mathrm{MgSO}_{4}$ per tanaman yang diaplikasikan dalam 3 tahap. Penetapan dosis pupuk magnesium dilakukan berdasarkan Uexkull (1992). Perlakuan pemupukan magnesium yang diberikan per bulan disajikan pada Tabel 1. Setiap kombinasi perlakuan diulang sebanyak 3 kali sehingga terdapat 48 satuan percobaan. Setiap satuan percobaan terdiri atas 5 tanaman, dengan demikian jumlah sampel seluruhnya adalah 240 tanaman.

Peubah pertumbuhan bibit tanaman yang diamati adalah tinggi tanaman, diameter batang, dan jumlah daun yang dilakukan setiap bulan. Peubah tinggi tanaman diukur dengan menggunakan meteran dan diameter batang menggunakan jangka sorong digital. Peubah fisiologi yang diamati adalah kandungan klorofil (metode SPAD-502 Plus chlorophyll meter), kerapatan stomata, dan kadar hara $\mathrm{Mg}$ anak daun (daun kelima), pelepah dan akar pada seluruh perlakuan dosis pupuk $\mathrm{Mg}$ pada dosis pupuk kalsium $20 \mathrm{~g}$ per bibit di akhir percobaan. Analisis jaringan tanaman dilakukan pada tanaman dengan dosis pupuk $\mathrm{Ca}$ tertinggi yaitu $20 \mathrm{~g}$ per tanaman karena pupuk Ca tidak memberikan pengaruh nyata pada hampir sebagian besar peubah morfologi dan fisiologi bibit kelapa sawit. Gradasi warna daun kelapa sawit ditentukan dengan menggunakan

Tabel 1. Perlakuan pemupukan magnesium yang diberikan secara bertahap

\begin{tabular}{lccccc}
\hline $\begin{array}{l}\text { Umur bibit } \\
\text { (bulan) }\end{array}$ & Kontrol & Perlakuan 1 & Perlakuan 2 & Perlakuan 3 & $\begin{array}{c}\text { Frekuensi } \\
\text { pemupukan per } \\
\text { bulan }\end{array}$ \\
\cline { 2 - 6 } & 0 & 1 & 2 & 4 & 1 \\
$3-2$ & 0 & 2 & 4 & 8 & 1 \\
$4-8$ & 0 & 4 & 8 & 16 & 1 \\
\hline Total & 0 & 24 & 48 & 96 & 8 \\
\hline
\end{tabular}


color reader. Color reader mempunyai sistem notasi warna hunter (sistem warna L, a, dan b). Notasi L menunjukkan parameter kecerahan (brigthness) dengan nilai 0 (hitam) sampai 100 (putih), notasi a dan b merupakan koordinatkoordinat kromatisitas, yaitu menunjukkan warna kromatik campuran merah hijau dengan nilai +a dari 0 sampai +60 untuk warna merah dan -a dari 0 sampai -60 untuk warna hijau. Nilai b menunjukkan warna kromatik campuran kuning biru dengan nilai $+\mathrm{b}$ dari 0 sampai +60 untuk warna kuning dan nilai -b dari 0 sampai -60 untuk warna biru. Sampel daun yang diamati adalah daun ke-5 yang dihitung dari atas (daun paling muda). Penghitungan dilakukan pada tiga titik (pangkal, tengah dan ujung) yang berjarak $\pm 0.5 \mathrm{~cm}$ dari tepi leaflet.

Penyusunan rekomendasi pemupukan $\mathrm{Mg}$ dihitung dari rata-rata dosis optimum yang diperoleh dari persamaan regresi peubah tinggi tanaman dan diamater batang dari hasil pengamatan setiap bulan. Dosis optimum diperoleh dengan cara menurunkan persamaan regresi yang diperoleh dari analisis statistik (Luthfyrakhman dan Susila, 2013). Analisis data menggunakan analisis varian (sidik ragam). Jika hasil analisis berpengaruh nyata maka dilanjutkan dengan uji kontras polinomial dan uji regresi untuk menentukan dosis optimum. Perhitungan data dilakukan dengan menggunakan SAS (Statistical Analysis System).

\section{HASIL DAN PEMBAHASAN}

\section{Tanggap Morfologi Tanaman}

Pemberian pupuk $\mathrm{Ca}$ tidak memberikan pengaruh nyata pada peubah tinggi tanaman, jumlah daun dan diameter batang. Pemberian pupuk $\mathrm{Mg}$ menyebabkan respon linier saat umur 3 BSP (bulan setelah perlakuan) dan respon kuadratik saat umur 4-8 BSP pada peubah tinggi tanaman bibit kelapa sawit (Tabel 2). Pemberian pupuk Mg menyebabkan respon linier saat umur 5-6 BSP dan respon kuadratik saat umur 4, 7 dan 8 BSP pada peubah jumlah daun (Tabel 3). Pemberian pupuk Mg menyebabkan respon linier pada 4 BSP dan respon kuadratik saat umur 3-8 BSP pada peubah diameter batang (Tabel 4).

Hasil sidik ragam menunjukkan bahwa tidak terdapat pengaruh interaksi antara pupuk kalsium dan magnesium terhadap peubah tanggap morfologi. Respon linier menunjukkan bahwa peubah yang diamati diduga masih akan meningkat seiring penambahan dosis pupuk yang diberikan. Respon kuadratik menunjukkan bahwa semakin tinggi dosis yang diberikan cenderung menurunkan pertumbuhan bibit kelapa sawit sehingga terbentuk pola parabola (kuadratik).

Pemberian pupuk Ca tidak berpengaruh terhadap pertumbuhan vegetatif bibit kelapa sawit. Hal ini disebabkan karena unsur hara $\mathrm{Ca}$ bersifat slow release dengan volume pelepasan mendekati kapasitas akartanaman dalammenyerap unsur hara (Wigena et al., 2006). Dengan demikian, respon tanaman terhadap Ca relatif lambat.

Pemberian pupuk $\mathrm{Mg}$ berpengaruh terhadap pertumbuhan vegetatif bibit kelapa sawit. Hasil tersebut sesuai dengan penelitian Ejraei (2010) yaitu pemberian pupuk dengan dosis $120 \mathrm{mg}$ magnesium dan $80 \mathrm{mg}$ sulfur meningkatkan pertumbuhan bibit kelapa sawit sebesar 15\% dibandingkan dengan kontrol. Penelitian Kasno dan Nurjaya (2011) juga menunjukkan bahwa pemberian pupuk kiserit $\left(\mathrm{MgSO}_{4} 7 \mathrm{H}_{2} \mathrm{O}\right)$ nyata meningkatkan tinggi tanaman, diameter batang, dan bobot brangkasan basah dan kering bibit tanaman kelapa sawit pada tipe tanah Ultisol dan Oksisol. Penelitian tersebut juga menunjukkan bahwa dosis optimum pupuk kiserit untuk meningkatkan bobot kering bibit umur 6.5 bulan pada tanah tersebut adalah $0.8 \mathrm{~g}$ per tanaman.

\section{Tanggap Fisiologi Tanaman}

Perlakuan pupuk $\mathrm{Ca}$ dan $\mathrm{Mg}$ berpengaruh terhadap kerapatan stomata daun pada 8 BSP (Tabel 5). Pupuk Ca

Tabel 2. Tinggi tanaman $(\mathrm{cm})$ bibit kelapa sawit pada setiap taraf dosis pupuk kalsium dan magnesium pada 0-8 BSP

\begin{tabular}{lcccccccccc}
\hline \multirow{2}{*}{ Dosis pupuk } & \multirow{2}{*}{ Taraf } & \multicolumn{1}{c}{ BSP } \\
\cline { 2 - 11 } & & 0 & 1 & 2 & 3 & 4 & 5 & 6 & 7 & 8 \\
\hline $\mathrm{CaCO}_{3}$ & 0 & 44.04 & 45.22 & 48.89 & 61.13 & 74.12 & 89.87 & 109.89 & 120.44 & 147.84 \\
(g per tanaman) & 5 & 45.94 & 45.99 & 50.23 & 62.87 & 78.48 & 90.17 & 110.86 & 120.20 & 148.93 \\
& 10 & 44.71 & 45.47 & 49.20 & 61.58 & 74.09 & 88.93 & 107.85 & 118.19 & 144.43 \\
& 20 & 43.99 & 44.66 & 48.5 & 61.90 & 73.88 & 87.55 & 104.96 & 118.34 & 140.55 \\
\hline Respon & & tn & tn & tn & tn & tn & tn & tn & tn & tn \\
\hline MgSO $_{4} 7 \mathrm{H}_{2} \mathrm{O}$ & 0 & 45.64 & 47.04 & 49.62 & 57.75 & 67.45 & 86.81 & 104.55 & 113.58 & 136.51 \\
(g per tanaman) & 24 & 44.60 & 44.93 & 48.45 & 61.65 & 76.76 & 88.25 & 106.93 & 118.32 & 145.85 \\
& 48 & 44.77 & 44.99 & 49.05 & 64.22 & 79.12 & 94.11 & 114.44 & 126.02 & 156.82 \\
& 96 & 43.67 & 44.39 & 49.69 & 63.86 & 77.24 & 87.34 & 107.64 & 119.26 & 142.55 \\
\hline Peluang & & & & & 0.001 & 0.041 & 0.023 & 0.025 & 0.016 & 0.000 \\
Respon & & tn & tn & tn & $\mathrm{L}^{* *}$ & $\mathrm{Q}^{*}$ & $\mathrm{Q}^{*}$ & $\mathrm{Q}^{*}$ & $\mathrm{Q}^{*}$ & $\mathrm{Q}^{* *}$ \\
\hline
\end{tabular}

Keterangan: $* * *=$ berpengaruh nyata pada taraf $5 \%$ dan $1 \%$; $\mathrm{tn}=$ tidak berpengaruh nyata; $\mathrm{L}=$ Linier; $\mathrm{Q}=$ Kuadratik 
Tabel 3. Jumlah daun (helai) bibit kelapa sawit pada setiap taraf dosis pupuk kalsium dan magnesium pada 0-8 BSP

\begin{tabular}{|c|c|c|c|c|c|c|c|c|c|c|}
\hline \multirow{2}{*}{ Dosis pupuk } & \multirow{2}{*}{ Taraf } & \multicolumn{9}{|c|}{ BSP } \\
\hline & & 0 & 1 & 2 & 3 & 4 & 5 & 6 & 7 & 8 \\
\hline $\mathrm{CaCO}_{3}$ & 0 & 6.8 & 7.7 & 8.9 & 10.2 & 11.7 & 13.3 & 14.3 & 15.3 & 16.6 \\
\hline \multirow[t]{3}{*}{ (g per tanaman) } & 5 & 6.7 & 7.7 & 9.2 & 10.3 & 11.8 & 13.7 & 14.5 & 15.1 & 16.8 \\
\hline & 10 & 6.6 & 7.7 & 8.8 & 9.9 & 11.7 & 13.3 & 14.3 & 15.1 & 16.8 \\
\hline & 20 & 6.7 & 7.7 & 8.9 & 10.3 & 11.8 & 13.5 & 14 & 15.0 & 16.7 \\
\hline Respon & & th & tn & tn & tn & tn & tn & $\operatorname{tn}$ & tn & tn \\
\hline $\mathrm{MgSO}_{4} 7 \mathrm{H}_{2} \mathrm{O}$ & 0 & 6.8 & 7.7 & 8.9 & 10.2 & 11.2 & 13.1 & 13.7 & 14.1 & 15.9 \\
\hline \multirow[t]{3}{*}{ (g per tanaman) } & 24 & 6.7 & 7.6 & 8.9 & 10.1 & 11.8 & 13.2 & 14.0 & 15.2 & 16.7 \\
\hline & 48 & 6.7 & 7.8 & 9.0 & 10.1 & 11.8 & 14.0 & 15.1 & 15.7 & 17.5 \\
\hline & 96 & 6.6 & 7.7 & 8.9 & 10.3 & 12.2 & 13.4 & 14.4 & 15.4 & 16.9 \\
\hline Peluang & & & & & & 0.022 & 0.007 & 0.001 & 0.009 & 0.009 \\
\hline Respon & & tn & tn & tn & tn & $\mathrm{Q}^{*}$ & $\mathrm{~L}^{* *}$ & $\mathrm{~L}^{* *}$ & $\mathrm{Q}^{* *}$ & $\mathrm{Q}^{* *}$ \\
\hline
\end{tabular}

Keterangan: $* * *=$ berpengaruh nyata pada taraf $5 \%$ dan $1 \%$; $\mathrm{tn}=$ tidak berpengaruh nyata; $\mathrm{L}=$ Linier; $\mathrm{Q}=$ Kuadratik; $\mathrm{BSP}=$ bulan setelah perlakuan

Tabel 4. Diameter batang $(\mathrm{cm})$ bibit kelapa sawit pada setiap taraf dosis pupuk kalsium dan magnesium pada 0-8 BSP

\begin{tabular}{|c|c|c|c|c|c|c|c|c|c|c|}
\hline \multirow{2}{*}{ Dosis pupuk } & \multirow{2}{*}{ Taraf } & \multicolumn{9}{|c|}{ BSP } \\
\hline & & 0 & 1 & 2 & 3 & 4 & 5 & 6 & 7 & 8 \\
\hline $\mathrm{CaCO}_{3}$ & 0 & 1.34 & 1.64 & 2.31 & 3.15 & 4.74 & 5.91 & 6.86 & 7.79 & 8.6 \\
\hline \multirow[t]{3}{*}{ (g per tanaman) } & 5 & 1.37 & 1.75 & 2.46 & 3.37 & 5.01 & 5.94 & 6.95 & 7.78 & 8.83 \\
\hline & 10 & 1.41 & 1.74 & 2.47 & 3.3 & 4.74 & 5.77 & 6.9 & 7.78 & 8.69 \\
\hline & 20 & 1.35 & 1.72 & 2.44 & 3.39 & 5.08 & 5.84 & 6.89 & 7.75 & 8.85 \\
\hline Respon & & tn & tn & tn & tn & tn & tn & tn & tn & tn \\
\hline $\mathrm{MgSO}_{4} 7 \mathrm{H}_{2} \mathrm{O}$ & 0 & 1.39 & 1.75 & 2.45 & 2.85 & 4.37 & 5.64 & 6.53 & 7.35 & 8.13 \\
\hline \multirow[t]{3}{*}{ (g per tanaman) } & 24 & 1.37 & 1.65 & 2.32 & 3.42 & 5.1 & 5.73 & 6.79 & 7.56 & 8.64 \\
\hline & 48 & 1.34 & 1.72 & 2.5 & 3.52 & 5.11 & 6.36 & 7.5 & 8.57 & 9.49 \\
\hline & 96 & 1.36 & 1.73 & 2.41 & 3.41 & 4.99 & 5.74 & 6.78 & 7.63 & 8.72 \\
\hline Peluang & & & & & 0.001 & $<.0001$ & 0.003 & 0.001 & 0.002 & $<.0001$ \\
\hline Respon & & tn & tn & tn & $\mathrm{Q}^{* *}$ & $\mathrm{~L} * *$ & $\mathrm{Q}^{* *}$ & $\mathrm{Q}^{* *}$ & $\mathrm{Q}^{* *}$ & $\mathrm{Q}^{* *}$ \\
\hline
\end{tabular}

Keterangan: $*, *=$ berpengaruh nyata pada taraf $5 \%$ dan $1 \%$; $\mathrm{tn}=$ tidak berpengaruh nyata; $\mathrm{L}=$ Linier; $\mathrm{Q}=$ Kuadratik; $\mathrm{BSP}=$ bulan setelah perlakuan

menyebabkan respon linier dan pupuk $\mathrm{Mg}$ menyebabkan respon kuadratik. Hal ini terkait dengan fungsi kalsium sebagai second messenger di dalam tanaman, meregulasi ion dalam channel, khususnya regulasi $\mathrm{K}^{+}$dalam channel, sehingga stomata menutup dan menghambat pembukaan stomata (Dodd et al., 2010; Webb dan Robertson, 2011; Laanemets et al., 2013). Pembukaan dan penutupan stomata berpengaruh pada laju fotosintesis (Palit, 2008; Khazaei et al., 2010).

Pemberian pupuk $\mathrm{Ca}$ tidak memberikan pengaruh nyata pada peubah kandungan klorofil daun. Pemberian pupuk Mg menyebabkan respon linier saat umur 4-6 BSP dan respon kuadratik saat umur 7-8 BSP pada peubah kandungan klorofil daun (Tabel 5). Hal ini berkaitan dengan fungsi hara $\mathrm{Mg}$ sebagai pusat penyusun klorofil
(Cakmak dan Kirkby, 2008), sehingga Mg dikaitkan dengan perkembangan klorofil daun (Hermans et al., 2006). Penurunan kadar klorofil akan berpengaruh pada kuantitas dan kualitas fotosintat yang diproduksi oleh tanaman kelapa sawit (Otitoju dan Onwurah, 2010).

Gambar 1 menyajikan hubungan nilai tingkat kecerahan(L), a (absis) dan b (ordinat) yang menggambarkan kandungan klorofil. Nilai L (tingkat kecerahan) berdasarkan dosis pupuk magnesium $0,24,48$, dan 96 g per tanaman berturut-turut adalah 34.76, 35.74, 35.98 dan 36.37. Warna daun dengan pemberian pupuk magnesium menunjukkan nilai L lebih tinggi dibandingkan dengan kontrol. Nilai L semakin meningkat sesuai dengan dosis pupuk magnesium yang diberikan. Nilai a (absis) dan b (ordinat) berdasarkan dosis pupuk Mg 0, 24, 48, dan 96 g per tanaman berturut- 


\section{J. Agron. Indonesia 43 (1) : 81 - 88 (2015)}

Tabel 5. Kandungan klorofil dan kerapatan stomata daun bibit kelapa sawit pada setiap taraf dosis pupuk kalsium dan magnesium pada 3-8 BSP

\begin{tabular}{|c|c|c|c|c|c|c|c|c|}
\hline \multirow[t]{2}{*}{ Dosis pupuk } & \multirow[t]{2}{*}{ Taraf } & \multicolumn{6}{|c|}{ Kandungan klorofil $\left(\mathrm{mg} \mathrm{cm}^{-2}\right)$} & \multirow{2}{*}{$\begin{array}{c}\begin{array}{c}\text { Kerapatan } \\
\text { stomata }\left(\mathrm{mm}^{2}\right)\end{array} \\
8 \mathrm{BSP}\end{array}$} \\
\hline & & $3 \mathrm{BSP}$ & $4 \mathrm{BSP}$ & $5 \mathrm{BSP}$ & $6 \mathrm{BSP}$ & $7 \mathrm{BSP}$ & 8 BSP & \\
\hline $\mathrm{CaCO}_{3}$ & 0 & 0.039 & 0.040 & 0.042 & 0.040 & 0.040 & 0.037 & 114.65 \\
\hline \multirow[t]{3}{*}{ (g per tanaman) } & 5 & 0.039 & 0.039 & 0.041 & 0.040 & 0.039 & 0.037 & 95.12 \\
\hline & 10 & 0.038 & 0.039 & 0.041 & 0.039 & 0.041 & 0.035 & 100.00 \\
\hline & 20 & 0.039 & 0.038 & 0.041 & 0.039 & 0.038 & 0.037 & 90.87 \\
\hline Peluang & & & & & & & & 0.004 \\
\hline Respon & & $\operatorname{tn}$ & $\operatorname{tn}$ & $\operatorname{tn}$ & $\operatorname{tn}$ & $\operatorname{tn}$ & $\operatorname{tn}$ & $\mathrm{L}^{* *}$ \\
\hline $\mathrm{MgSO}_{4} 7 \mathrm{H}_{2} \mathrm{O}$ & 0 & 0.039 & 0.036 & 0.038 & 0.037 & 0.036 & 0.033 & 87.26 \\
\hline \multirow[t]{3}{*}{ (g per tanaman) } & 24 & 0.038 & 0.039 & 0.042 & 0.039 & 0.039 & 0.036 & 99.58 \\
\hline & 48 & 0.040 & 0.040 & 0.043 & 0.042 & 0.040 & 0.038 & 111.89 \\
\hline & 96 & 0.038 & 0.039 & 0.042 & 0.040 & 0.042 & 0.039 & 101.91 \\
\hline Peluang & & & 0.000 & 0.001 & 0.001 & 0.022 & 0.019 & 0.035 \\
\hline Respon & & th & $\mathrm{L}^{* *}$ & $\mathrm{~L}^{* *}$ & $\mathrm{~L} * *$ & $Q^{*}$ & $\mathrm{Q}^{*}$ & $\mathrm{Q}^{*}$ \\
\hline
\end{tabular}

Keterangan: *,* = berpengaruh nyata pada taraf $5 \%$ dan $1 \%$; $\mathrm{tn}=$ tidak berpengaruh nyata; $\mathrm{L}=$ Linier; $\mathrm{Q}=$ Kuadratik; $\mathrm{BSP}=$ bulan setelah perlakuan

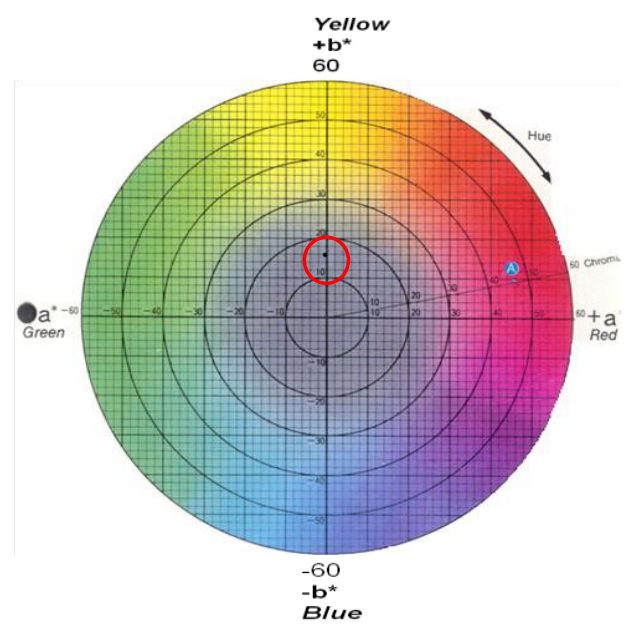

(A)

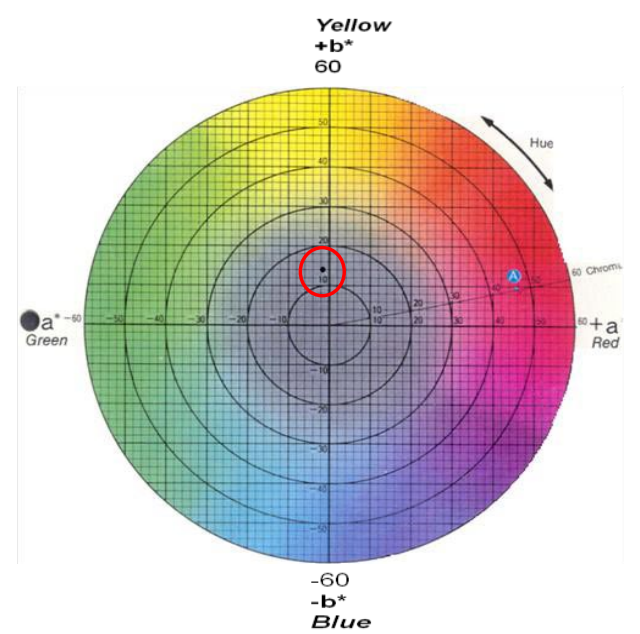

(C)

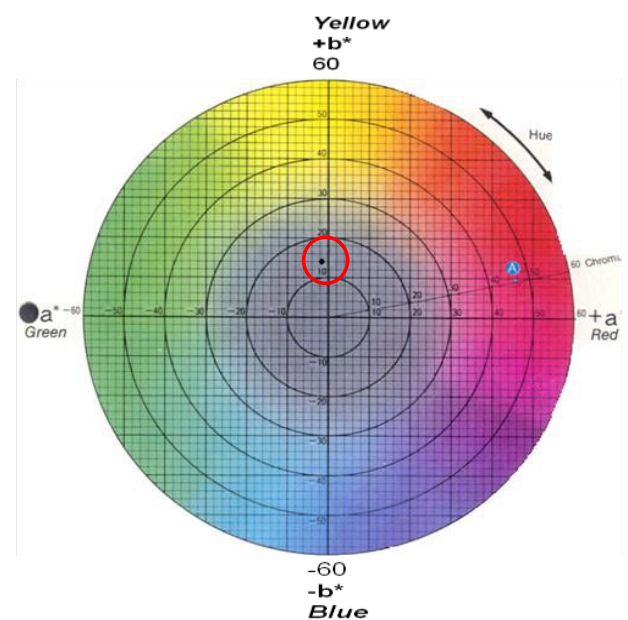

(B)

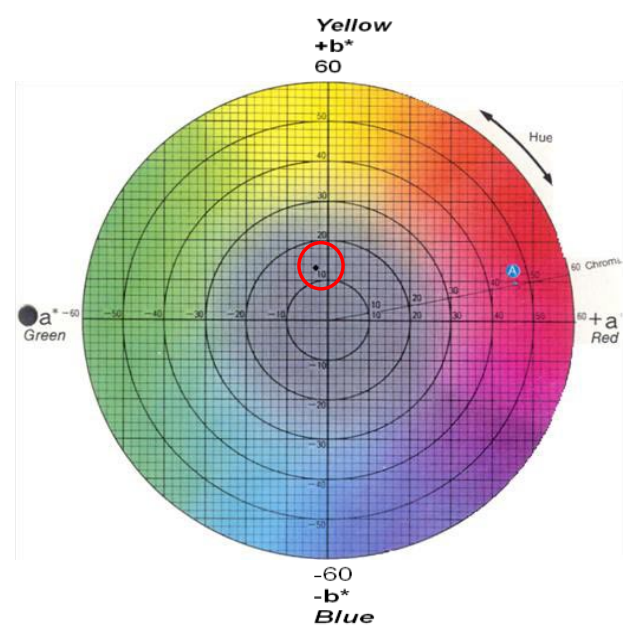

(D)

Gambar 1. Diagram warna daun bibit kelapa sawit pada berbagai perlakuan dosis magnesium: (A) 0; (B) 24; (C) 48; dan (D) $96 \mathrm{~g}$ $\mathrm{MgSO}_{4}$ per tanaman 


\section{J. Agron. Indonesia 43 (1) : 81 - 88 (2015)}

turut adalah $-1.36,14.78 ;-1.93,13.15 ;-1.91,13.40$ dan $2.33,12.73$. Nilai a semakin rendah dengan banyaknya pupuk magnesium yang diberikan. Hal ini menunjukkan jika nilai a semakin rendah maka warna daun tanaman semakin hijau. Nilai b semakin tinggi dengan perlakuan tanpa pemberian pupuk magnesium. Hal ini menunjukkan jika nilai b semakin tinggi maka daun akan berwarna kekuningan yang memberi indikasi gejala klorosis.

Pemberian unsur $\mathrm{Mg}$ berpengaruh nyata secara kuadratik terhadap kandungan Mg dalam jaringan tanaman.
Berdasarkan data tersebut dapat diketahui bahwa kandungan hara magnesium pada jaringan vegetatif dengan pemberian pupuk magnesium lebih tinggi dibandingkan dengan kontrol. Rata-rata kandungan $\mathrm{Ca}$ dan $\mathrm{Mg}$ pada jaringan tanaman dengan dosis $0 \mathrm{~g}$ per tanaman sebesar $0.33 \%$ dan $0.15 \%$ dan pada dosis $96 \mathrm{~g}$ per tanaman sebesar $0.28 \%$ dan $0.24 \%$ (Tabel 6). Kandungan $\mathrm{Ca}$ dan $\mathrm{Mg}$ dalam jaringan tanaman bibit kelapa sawit pada percobaan ini berada pada zona cukup. Kadar Ca pada tanaman kelapa sawit berkisar sebesar $0.14 \%$ pada bibit dan $0.25 \%$ pada tanaman dewasa.

Tabel 6. Kadar hara Ca dan Mg pada jaringan akar, pelepah dan daun bibit kelapa sawit saat umur 8 bulan setelah perlakuan dengan berbagai dosis pupuk magnesium pada dosis kalsium 20 g per bibit

\begin{tabular}{lccccccccc}
\hline \multirow{2}{*}{ Dosis pupuk } & Taraf & \multicolumn{2}{c}{$\begin{array}{c}\text { Kadar hara } \\
\text { akar (\%) }\end{array}$} & \multicolumn{2}{c}{$\begin{array}{c}\text { Kadar hara } \\
\text { pelepah (\%) }\end{array}$} & \multicolumn{2}{c}{$\begin{array}{c}\text { Kadar hara } \\
\text { daun (\%) }\end{array}$} & \multirow{2}{*}{$\begin{array}{c}\text { Kadar Ca dalam } \\
\text { jaringan tanaman (\%) }\end{array}$} & $\begin{array}{c}\text { Kadar Mg dalam } \\
\text { jaringan tanaman (\%) }\end{array}$ \\
\cline { 2 - 9 } & & $\mathrm{Ca}$ & $\mathrm{Mg}$ & $\mathrm{Ca}$ & $\mathrm{Mg}$ & $\mathrm{Ca}$ & $\mathrm{Mg}$ & 0.33 & 0.15 \\
\hline MgSO$_{4} 7 \mathrm{H}_{2} \mathrm{O}$ & 0 & 0.21 & 0.08 & 0.21 & 0.12 & 0.59 & 0.26 & 0.21 \\
(g per tanaman) & 24 & 0.13 & 0.11 & 0.22 & 0.21 & 0.54 & 0.30 & 0.30 & 0.22 \\
& 48 & 0.09 & 0.12 & 0.22 & 0.22 & 0.56 & 0.33 & 0.29 & 0.24 \\
\hline Peluang & 96 & 0.13 & 0.16 & 0.18 & 0.21 & 0.52 & 0.35 & 0.28 & \\
Respon & & & 0.041 & & 0.023 & & 0.045 & & \\
\hline
\end{tabular}

Keterangan: $* * *=$ berpengaruh nyata pada taraf $5 \%$ dan $1 \%$; tn $=$ tidak berpengaruh nyata; $\mathrm{Q}=$ Kuadratik

Tabel 7. Penentuan dosis optimum magnesium $(\mathrm{Mg})$ pada bibit kelapa sawit di pembibitan utama berdasarkan peubah tinggi tanaman dan diameter batang

\begin{tabular}{|c|c|c|c|c|}
\hline Peubah & Umur (BSP) & Persamaan regresi & $\mathrm{R}^{2}$ & $\begin{array}{l}\text { Dosis optimum } \\
\text { (g per bibit) }\end{array}$ \\
\hline \multirow[t]{9}{*}{ Tinggi tanaman } & 1 & Dosis rekomendasi & - & $2.0^{*}$ \\
\hline & 2 & Dosis rekomendasi & - & $2.0^{*}$ \\
\hline & 3 & $y=0.355 x+59.38$ & 0.66 & $4.0^{*}$ \\
\hline & 4 & $y=-0.116 x^{2}+2.435 x+67.84$ & 0.97 & 10.5 \\
\hline & 5 & $y=-0.087 x^{2}+1.502 x+85.95$ & 0.73 & 8.6 \\
\hline & 6 & $y=-0.103 x^{2}+1.939 x+103.5$ & 0.76 & 9.4 \\
\hline & 7 & $y=-0.127 x^{2}+2.470 x+112.7$ & 0.88 & 9.7 \\
\hline & 8 & $y=-0.231 x^{2}+4.165 x+135.5$ & 0.92 & 9.0 \\
\hline & Total & & & 55.3 \\
\hline \multirow[t]{9}{*}{ Diameter batang } & 1 & Dosis rekomendasi & - & $2.0^{*}$ \\
\hline & 2 & Dosis rekomendasi & - & $2.0^{*}$ \\
\hline & 3 & $y=-0.006 x^{2}+0.142 x+2.884$ & 0.96 & 11.8 \\
\hline & 4 & $y=0.004 x+4.686$ & 0.32 & $8.0^{*}$ \\
\hline & 5 & $y=-0.08 x^{2}+1.421 x+55.47$ & 0.66 & 8.9 \\
\hline & 6 & $y=-0.107 x^{2}+1.952 x+64.37$ & 0.78 & 9.1 \\
\hline & 7 & $y=-0.130 x^{2}+2.375 x+72.10$ & 0.70 & 9.1 \\
\hline & 8 & $y=-0.140 x^{2}+2.692 x+80.43$ & 0.88 & 9.6 \\
\hline & Total & & & 60.5 \\
\hline Rata-rata & & & & 58.0 \\
\hline
\end{tabular}

Keterangan: * Dosis tersebut ditentukan respon linier; $\mathrm{BSP}=$ bulan setelah perlakuan 
Kadar Mg pada tanaman kelapa sawit berkisar $0.22 \%$ pada bibit dan $0.16 \%$ pada tanaman dewasa ( $\mathrm{Ng}$ et al., 1968).

\section{Penentuan Kebutuhan Pupuk dan Rekomendasi}

Penyusunan rekomendasi pemupukan $\mathrm{Mg}$ dihitung dari rata-rata dosis optimum yang diperoleh dari persamaan regresi peubah tinggi tanaman dan diamater batang dari hasil pengamatan setiap bulan. Peubah morfologi menunjukkan bahwa dosis optimum pupuk Mg saat umur 1 dan 2 BSP (bulan setelah perlakuan) tidak tercapai sehingga dosis yang digunakan adalah dosis rekomendasi Uexkull (1992). Pemberian pupuk Mg baru terlihat saat umur 3 BSP pada peubah tinggi tanaman dan diameter batang. Saat tanaman berumur 3 BSP, pupuk Mg berpengaruh pada peubah tinggi tanaman secara linier dengan persamaan regresi $\mathrm{y}=0.355 \mathrm{x}$ + 59.38. Persamaan linier tidak memiliki titik optimum sehingga dosis optimum pupuk $\mathrm{Mg}$ adalah dosis tertinggi yaitu 4 g per tanaman. Saat tanaman berumur 4 BSP pada peubah tinggi tanaman pupuk $\mathrm{Mg}$ menunjukkan respon kuadratik sehingga terbentuk pola parabola (kuadratik) sehingga dosis optimum diturunkan dari persamaan regresi. Saat tanaman berumur 4 BSP, persamaan regresinya adalah $y=-0.116 x^{2}+2.435 x+67.84$. Dari model regresi tersebut dosis optimum pupuk $\mathrm{Mg}$ adalah $10.5 \mathrm{~g}$ per tanaman. Penentuan dosis optimum magnesium $(\mathrm{Mg})$ pada bibit kelapa sawit di pembibitan utama berdasarkan peubah tinggi tanaman dan diameter batang dilihat pada Tabel 7 .

\section{KESIMPULAN}

Pemberian pupuk kalsium berpengaruh pada kerapatan stomata. Pemberian pupuk magnesium berpengaruh nyata terhadap peubah vegetatif dan fisiologi bibit kelapa sawit yaitu kerapatan stomata dan kandungan klorofil. Tidak terdapat interaksi antara perlakuan pupuk kalsium dan magnesium pada bibit kelapa sawit. Berdasarkan peubah tinggi tanaman dan diameter batang maka dosis optimum pupuk magnesium bibit kelapa sawit selama 8 bulan di pembibitan utama adalah $58 \mathrm{~g}$ per tanaman. Dosis pupuk $\mathrm{Mg}$ tersebut diaplikasikan setiap bulannya dalam jumlah yang berbeda pada umur 1-8 bulan, berturut-turut adalah 2.0, 2.0, 8.0, 9.3, 8.8, 9.3, 9.4 dan 9.3 $\mathrm{g} \mathrm{MgSO}_{4}$ per tanaman. Dosis optimum pupuk kalsium tidak dapat ditentukan pada penelitian ini.

\section{DAFTAR PUSTAKA}

Baker, A.V., D.J. Pilbean. 2006. Hunger Sign in Crops. In Handbook of Plants Nutrition 117. CRC Pr, Florida, USA.

Cakmak, J., E.A. Kirkby. 2008. Role of magnesium in carbon partitioning and alleviating photo oxidative damage. Plant Physiol.133:692-704.

Cakmak, I., A. Yazici. 2010. Magnesium: A forgotten element in crop production. Better Crops 94:23-25.
[Ditjenbun] Direktorat Jendral Perkebunan. 2013. Produksi, luas areal dan produktivitas perkebunan di Indonesia. Indonesia.

Dodd, A.N., J. Kudla, D. Sanders . 2010. The language of calcium signaling. Ann. Rev. Plant Biol. 61:593620 .

Ejraei, A. 2010. Interaction of sulfur and magnesium on palm oil seed. ISHS Acta Horticulturae 882(85):IV International Date Palm Conference. http://www. actahort. org [28 Pebruari 2013].

Fairhurst, T.H., J.P. Caliman, R. Härdter, C. WITT. 2006. Kelapa sawit: kelainan hara dan pengelolaannya. Potash and Phosphate Institute (PPI), Potash and Phosphate Institute of Canada (PPIC), International Potash Institute (IPI), French Agricultural Research Centre for International Development (CIRAD).

Gransee, A., A. Fuhrs. 2012. Magnesium mobility in soils as a challenge for soil and plant analysis, magnesium fertilization and root uptake under adverse growth conditions. Plant Soil 368:5-21.

Hermans, C., J.P. Hammond, P.J. White, N. Verbruggen. 2006. How do plants respond to nutrient shortage by biomass allocation?. Trends Plant Sci. 11:610-617.

Kasno, A., Nurjaya. 2011. Pengaruh pupuk kiserit terhadap pertumbuhan kelapa sawit dan produktivitas tanah. J. Littri 17:133-139.

Khazaei, H., P. Monneveux, S. Hongbo, S. Mohammady. 2010. Variation for stomatal characteristics and water use efficiency among diploid, tetraploid and hexaploid Iranian wheat landraces. Genet. Resour. Crop Evol. 57:307-314.

Laanemets, K., B. Brandt, J. Li, E. Merilo. 2013. Calciumdependent and -independent stomatal signaling network and compensatory feedback control of stomatal opening via $\mathrm{Ca}^{2+}$ sensitivity priming. Plant Physiol.163:504-513.

Luthfyrakhman, H., A.D. Susila. 2013. Optimasi dosis pupuk anorganik dan pupuk kandang ayam pada budidaya tomat hibrida (Lycopersicon esculentum Mill. L.). Bul. Agrohorti 1:119-126.

MPOB (Malaysian Palm Oil Board). 2011. Malaysian palm oil industry. http://www.palmoilworld.org [22 Juli 2013].

Ng, S.K., S. Thamboo, P. de Souza. 1968. Nutrient contents of oil palms in Malaya. Malaysian Agric. J. 46:332391. 
Otitoju, O., I.N.E. Onwurah. 2010. Chlorophyll contents of oil palm (Elaeis Guineensis) leaves harvested from crude oil polluted soil: a shift in productivity dynamic. Annals Biol. Res. 1:20-27.

Oviasogie, P.O., A.E. Aghimien, M.O. Ekebafe. 2011. Chemical fractionation of magnesium in soil cultivated to the oil palm. Nig. J. Life Sci. 1:53-57.

Palit, J.J. 2008. Teknik penghitungan jumlah stomata beberapa kultivar kelapa. Bul. Teknik Pertanian 13:911 .

Tuteja, N., S. Mahajan. 2007. Further characterization of calcineurin B-like protein and its interacting partner CBL-interacting protein kinase from Pisum sativum. Plant Signal Behav. 2:358-361.

Uexkull, H.R. 1992. Oil palm (Elaeis guineensis Jacq.). International Potash Institute, Singapura.
Wachjar, A., L. Kadarisman. 2007. Pengaruh kombinasi pupuk organik cair dan pupuk anorganik serta frekuensinya terhadap pertumbuhan tanaman kakao (Theobrama cacao L.) belum menghasilkan. Bul. Agron. 35:212-216.

Webb, A.A.R., F.C. Robertson. 2011. Calcium signals in the control of stomatal movements. Signaling Comm. Plants 642:63-77.

Wigena, I.G.P., J. Purnomo, E. Tuberkih, A. Saleh. 2006. Pengaruh pupuk "Slow Release" majemuk padat terhadap pertumbuhan dan produksi kelapa sawit muda pada Xanthic Hapludox di Merangin, Jambi. J. Tanah Iklim 24:10-19.

Yang, G.H., L.T. Yang, H.X. Jiang. 2012. Physiological impacts of magnesium-deficiency in Citrus seedlings: photosynthesis, antioxidant system and carbohydrates. Trees 26:1237-1250. 